\title{
The Natural Dynamics of the Diversity of Small Mammal's Communities in Primary Forests in the Central of the Caspian-Baltic Watershed
}

\author{
Anatoly Istomin ${ }^{1,2}$, Sergey Mikhalap ${ }^{1}$ \\ ${ }^{1}$ Pskov State University; Natural Sciences, Medical and Psychological Education Faculty Address: Sovetskaya \\ St. 21, Pskov, 180000, Russia; \\ ${ }^{2}$ Central Forest State Nature Biosphere Reserve, Russia, Tver Region
}

\begin{abstract}
Diversity is one of the main characteristics of the system, which reflects its complexity and structure. Diversity of biotic communities is always being actively discussed in the consideration of their organization, functioning, and sustainability. However, many questions still remain debatable. The report deals with the results of long-term (1980-2015) studies of the diversity of micromammalia communities in the primary ecosystems of southern Taiga of the Central Forest State Natural Biosphere Reserve (Russia), which is located in the centre of the Caspian-Baltic watershed. The diversity change of small mammals' communities was connected with climatic trends, extreme and catastrophic climatic phenomena. The authors offer methods of research and evaluation of $\alpha$ - and $\beta$-diversity of communities in conditions of the continuum of the environment of primary forests with the use of the gradient approach and GIS analysis.

Keywords: biodiversity monitoring; $\alpha$ - and $\beta$-diversity of communities; small mammals' communities; primary forests; continuity environment; gradients of the environment; GIS analysis.
\end{abstract}

\section{INTRODUCTION}

One of the main measurable characteristics of the system is diversity, which reflects its complexity and structuredness. Diversity is always actively discussed when considering the organization, functioning, and stability of biotic communities, including responses to changes in the environment. However, quite a few questions are still discussed [1-7]. The multi-species groups of small mammals play an important cenotic role in ecosystems and are a universal model objects for different studies including biodiversity monitoring. Inventory and differentiation species diversity of small mammals' communities was investigated in the natural dynamics of the reference forest ecosystems of the European southern taiga. In addition to traditional methods for assessing the species diversity of communities in the conditions of the mosaic-continual habitat of the south-taiga forests the researchers used a complex gradient approach and the GIS-analysis.

\section{MATERIALS AND METHODS}

The basis for the article was the authors' longterm research which was carried out in 1981-2015 in the Central-Forest State Natural Biosphere Reserve located in the central part of the Caspian-Baltic watershed of the Russian Plain (Russia, the Tver Region). The climate of the territory is moderately continental with the determining effect of the warm
North-Atlantic current. The region belongs to the subzone of the southern taiga [8]. The vegetation cover is mainly represented by spruce and secondary forests formed in their place $(80 \%)$. Historical and paleoecological studies have shown that during the last millennium no more than $15 \%$ of the present territory of the reserve was developed [9]. Currently, the total proportion of anthropogenic habitats within the reserve is only $1.5 \%$. There are no obvious sources of atmospheric pollution within the shortrange territory. The Central Forest Reserve is a model area of natural processes of the southern taiga ecosystems of the Russian Plain.

The data for this work were obtained during the annual standard catches in stationary model areas of primary spruce forests of nemoral and boreal genesis. The total amount of the material is about 15,000 examples of small mammals of various species. Standard information measures were used for assessing the species diversity of communities: Shannon-Weaver index, Pielou's measure of species evenness [5]. As a measure of the differentiating species diversity of communities the authors used the Chekanovsky-Sörensen difference coefficient in the form $\mathrm{b}$ : Ics $=1-\sum \min (\mathrm{Pi}, \mathrm{y} ; \mathrm{Pi}, \mathrm{k})$, where $\mathrm{Pi}, \mathrm{y} ; \mathrm{Pi}, \mathrm{k}$ are the minimal species share in a pair of samples [7]. The results were verified by the T-test. http://dx.doi.org/10.17770/etr2017vol1.2629 
Since 2010 the spatial distribution of small mammal species in the continuum of forest ecosystems has been studied using a gradient long trap-line. Long trap-lines application is well proved in a number others studies of small mammals communities [10-12]. The transect, which is $2280 \mathrm{~m}$ long, crosses different types of indigenous ecosystems of the southern taiga, first of all spruce forests of various genesis. The transect is marked with 114 endorse points which are linked through the GPS to the WGS 84 coordinate system (UTM Zone 36 North). The distance between neighboring points is 20 meters. The points have detailed geobotanical descriptions in areas of $20 \times 20$ and $5 \times 5$ meters. The descriptions contain 275 variables primarily of the phytocenotic environment as well as some microrelief and microclimatic parameters. Within the transect area the researchers made catching of small mammals (1,700 exemplars). The distribution of rodents made it possible to identify unit cells of small mammals' habitats that are minimal natural zones for their livelihood. For this very purpose the researchers calculated the total and particular autocorrelation functions using summarized data of micromammalia species representation at each point of the transect trap-line. Statistical processing of data was carried out in the program STATISTICA-8.0.

\section{RESULTS AND DISCUSSION}

13 species of rodents and 6 species of shrews were recorded in the micromammalia communities of the reserve. Long-term regular observations showed that biodiversity indicators increased in this study period in the forest ecosystems of the reserve (Table 1). It is determined by a more evened representational distribution of typical forest species which primarily refers to the increased role of the Eastern Palearctic species (by 15 times) for boreal spruce forests. In the rodents' guilds of nemoral spruce forests there is an increase in representing some western Palearctic species that are located here on the edge of their range. Their total participation in the guild of rodents increased 10 times. The increase in the alphadiversity of rodent communities in native spruce forests was accompanied by a significant growth in the total number of species (Table 1).

Table I

Dynamics of Some Characteristics of Small Mammal Communities in the Spruce Forests of Different Genesis in the Period 1981-2015 Years.

\begin{tabular}{|c|c|c|c|c|}
\hline \multicolumn{2}{|l|}{ Features } & \multicolumn{3}{|c|}{ The nemoral spruce forests } \\
\hline $\begin{array}{l}\text { The total number of communities of small mammals } \\
\text { (individuals per } 100 \text { trap/nights) }\end{array}$ & $\mathrm{M} \pm \mathrm{m}$ & $24,5 \pm 5,7$ & $40,4 \pm 6,7$ & $60,0 \pm 5,5$ \\
\hline \multirow[t]{2}{*}{ Species diversity of rodents guilds } & $\mathrm{H}^{\prime}$ & 0,105 & 0,242 & 0,242 \\
\hline & $\mathrm{E}$ & 0,065 & 0,116 & 0,124 \\
\hline \multirow{2}{*}{$\begin{array}{l}\text { The total number of communities of small mammals } \\
\text { (individuals per } 100 \text { trap/nights) }\end{array}$} & Lim & $0-55,0$ & $8,0-64,8$ & $10,0-59,9$ \\
\hline & $\mathrm{M} \pm \mathrm{m}$ & $16,9 \pm 6,1$ & $31,8 \pm 6,3$ & $33,4 \pm 4,1$ \\
\hline \multirow{2}{*}{$\begin{array}{l}\text { The proportion of individuals of species in East Palearctic } \\
\text { species composition of the guilds (in \%) }\end{array}$} & rodents & $1,6 \%$ & $24,6 \%$ & $23,4 \%$ \\
\hline & shrews & $3,3 \%$ & $43,8 \%$ & $49,3 \%$ \\
\hline Species diversity of rodents guilds & $\mathrm{H}^{\prime}$ & 0,125 & 0,829 & 0,691 \\
\hline
\end{tabular}

Lim - limits, $\mathrm{M} \pm \mathrm{m}$ - the arithmetic mean with error, H'- the index of species diversity Shannon-Weaver $\left(\mathrm{H}^{\prime}=-\sum \mathrm{PilnPi}\right.$, где $\mathrm{Pi}-$ the

proportion of species in the community structure), E - equitability Pielou ( $E=\mathrm{H}^{\prime} / \ln \mathrm{s}$ где $\mathrm{S}$ - the number of species in the community)

In the 1980s groups of small mammals were much more homogeneous throughout the reserve. The degree of differences in the structure of rodent communities of nemoral and boreal spruce forests in 1981-1990 was insignificant (the mean of difference in Chekanovsky-Sörensen Index was 0.06). The value of a similar index in 1991-2015 was five times higher (0.31, $\mathrm{P}=0.999)$.

It proves the increase in the zonal contrast of climax spruce communities of different genesis. The increase in the heterogeneity of rodent communities in the later period of observations was detected not only among spruce forests of different genesis but also among individual model areas of the same genesis: for boreal spruce forests - 2 times, for nemoral spruce forests - 6-7 times. The growth in the heterotony of micromammalia guilds indicates the increase in the beta diversity of communities in the forests of the reserve in general.

The spatial heterogeneity of environment is known as one of the important factors in developing diversity in animal communities [2, 3, 5, 6, 13, 14]. As a rule, there is a fairly close positive relationship between the biodiversity and the structural complexity of the habitat. In our case the increase in the alpha-diversity of communities is apparently determined by the increase of the habitat heterogeneity as the result of massive windfall processes and a large-scale drying of spruce forests with their subsequent destruction, which led to the formation of an extremely mosaic plant cover. The obtained results are in good agreement with the modern forest GAP-paradigm considering that natural forests represent the succession mosaic of stains 
which are at different stages of ecosystems development and provide biodiversity and sustainability. It is not sufficient for a mosaic environment to use only discrete model sites to assess the diversity of communities because a lot of ecotone variants are not taken into consideration. Therefore, we used the gradient approach and in 2010-2014 small mammal catches were made on the long transect that was described above.

The analysis of the spatial numbers of rodents showed that this is not a chaotic sequence but an organized structure. In particular, for the dominant species in all types of forest ecosystems - Myodes (Clethrionomys) glareolus, the autocorrelation function with an increase in the shift (Lag) is decaying. However, the autocorrelation corresponding to a shift in 5 points (100 meters) and 13 points ( 260 meters) goes beyond the boundary of a monotonically damped process denoting the existence of a harmonic in the investigated series (Fig. 1). Q-statistics shows that the process is sure not to be random.

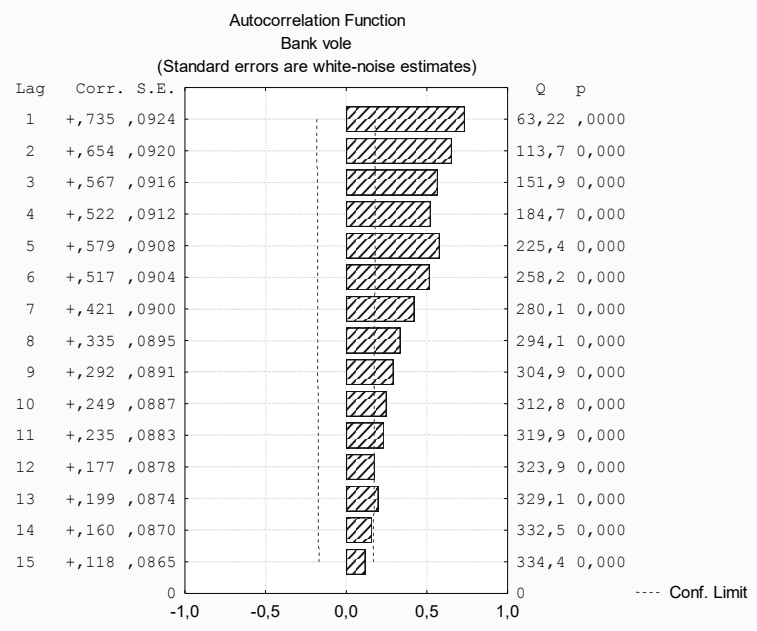

Fig. 1. Autocorrelation function of abundance bank vole

Analogous but more contrasting results were obtained in the analysis of a particular autocorrelation function (Fig. 2).

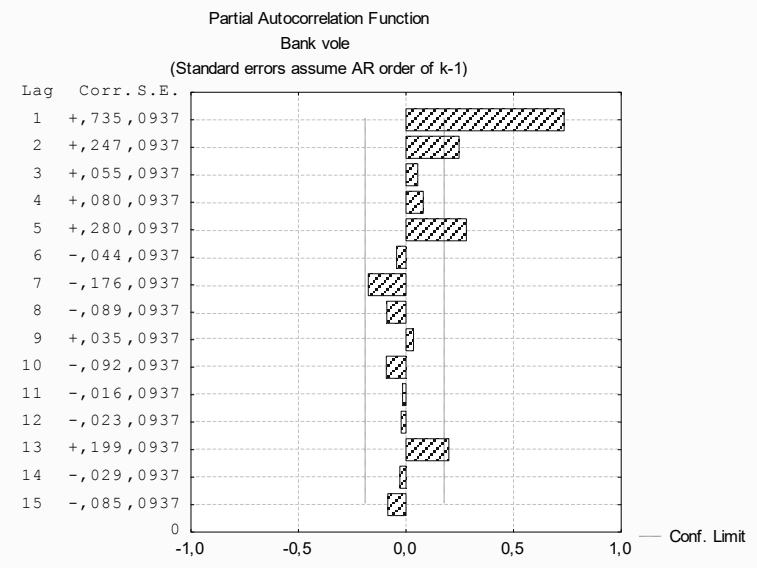

Fig.2. Partial autocorrelation function of abundance bank vole
Thus, the spatial series of bank voles' population in the continuum of the environment has a pronounced cycle character which represents a regularly repeated structure of territorial organization - the special unit cells. The two levels of community organization have been identified: cells of 100 to 100 meters and cells of 260 to 260 meters. Similar results were obtained for other rodent species studied. It indirectly indicates the certain synchrony in population processes in small mammals which is probably related to the Moran effect $[15,16]$.

This dimension of spatial cells is in a complete agreement with the data of some sources [17].

The model transect with the length of $2,280 \mathrm{~m}$ has 23 cells of $100 \mathrm{~m}$ in size and 9 cells with the dimension of $260 \mathrm{~m}$. For all cells the species structure of rodents' guilds was defined and the indices of difference between them were calculated. For the dimension of $100 \mathrm{~m}$ the matrix constitutes 253 paired comparisons, for the dimension of $260 \mathrm{~m}$ it constitutes 36 . The general results of the comparisons are presented in Table. 2 .

Table 2

Indicators Differentiating The Species Diversity Of Rodent Communities In Primary Spruce Forests

\begin{tabular}{|l|l|l|l|l|}
\hline $\begin{array}{l}\text { The size of } \\
\text { the spatial } \\
\text { cells (m) }\end{array}$ & $\mathrm{n}$ & The dissimilarity index & $\begin{array}{l}\text { Share reliable } \\
\text { comparisons } \\
(\mathrm{P}=0,95)\end{array}$ \\
\cline { 3 - 5 } & $\mathrm{Lim}$ & $\mathrm{M} \pm \mathrm{m}$ & $49 \%$ \\
\hline $100 \mathrm{~m}$ & 253 & $0,0-0,41$ & $0,16 \pm 0,07$ & $49 \%$ \\
\hline $260 \mathrm{~m}$ & 36 & $0,02-0,39$ & $0,15 \pm 0,04$ & $86 \%$ \\
\hline
\end{tabular}

For the special unit cells of $100 \mathrm{~m}$ and $260 \mathrm{~m}$ we obtained similar results. It refers to both the diapason and the average difference index. A higher proportion of reliably differing pairwise comparisons for the dimension of $260 \mathrm{~m}$ is determined by the larger $(2.5$ times on the average) number of samples used to describe the structure of communities than for the dimension of $100 \mathrm{~m}$.

The similarity of the obtained results to a certain extent proves the correctness of the allocated spatial unit cells and their application for characterizing the structure and diversity of forest communities of small mammals.

\section{CONCLUSIONS}

At the turn of the 20th and 21st centuries there were significant changes in the structure, diversity, and abundance of small mammals' communities in the etalon forest ecosystems of the central part of the Caspian-Baltic watershed, which arose as a response to the change of the structural and functional organization of the entire forest area of the CentralForest reserve. In many respects the observed tendencies are apparently determined by the climate fluctuations, the growth of the net production of forest ecosystems, and by the frequent catastrophic phenomena and extreme factors, the manifestation of 
which is associated with climate change [18-20]. In conditions of the southern taiga forests these trends cause periodic mass windfalls, a large-scale spruce stands desiccation entailing their subsequent destruction and the formation of an extremely mosaic plant cover. The active succession dynamics of forest ecosystems in the natural complexes of the reserve caused certain changes in population and small mammals' communities functioning, which is related to the natural large-scale destruction of forests ecosystems [18, 20].

In the conditions of mosaic forest ecosystems the proposed method for estimating the $\beta$-diversity of small mammal communities is quite applicable. This method involves the use of long gradient trap-lines, the allocation of spatial unit cells, and a comparative analysis of the similarity of the animal communities' structure.

\section{REFERENCES}

[1] R. H. Whittaker Dominance and diversity in land plant communities. Science, 1965 , vol.147, no. 365, pp. 250 -260.

[2] E.R.Pianka Latitudinal gradients in species diversity: A review of concepts // Amer. Nat. 1966. Vol. 100, N 910. pp. 33-46.

[3] E.R Pianka. Evolutionary ecology. - N. Y.; L. : Harper and Row, 1974. $-356 \mathrm{p}$

[4] R.H. Whittaker Communities and Ecosystems. New York, 1975. $327 \mathrm{p}$

[5] E. P.Odum Basic Ecology. Philadelphia: Sanders. 1983. $613 \mathrm{p}$.

[6] P.S. Giller Community Structure and the Niche. Chapman and Hall, London, 1984. 176 p.

[7] Pesenko Yu.A. Principles and methods of quantitative analysis in faunistic studies. Moscow: Nauka, 1982. 285 p.

[8] Factors of the regulation of spruce forest ecosystems. Leningrad : Nauka, 1983.318 p.

[9] Karimov A.E., Nosova M.B. The use of land and the impact on the nature of the Central Forest Reserve (late 16th-early 20th centuries) // Succession processes in Russian nature reserves and conservation of biological diversity. St. Petersburg. Russian Botanical Society, 1999. P. 299-310.

[10] Joan L. Morrison and Patricia L. Kennedy. The use of line transects to evaluate the abundance of diurnal mammalian prey. The Raptor Research Foundation, Inc. 23(4). 1989, pp. $172-175$

[11] José M. V. Fragoso, Taal Levi, Luiz F. B. Oliveira, Jeffrey B. Luzar, Han Overman, Jane M. Read, Kirsten M. Silvius.
Line Transect Surveys Underdetect Terrestrial Mammals: Implications for the Sustainability of Subsistence Hunting. PLoS ONE 11(4). 2016, pp. 1-18. Available at: DOI:10.1371/journal.pone.0152659, [Accessed: Mar. 5, 2017].

[12] Istomin A.V., Mikhalap S.G. The use of "gradient" traplines in the study of small mammals in natural conditions / / Intern. Conf. Actual problems of nature protection. Cheboksary., 2011. C.6-7.

[13] L. E. Lukyanova, O. A. Lukyanov An ecologically destabilized environment: Its effect on small-mammal populations Russian Journal of Ecology. 2004. T. 35. № 3. .P. $181-188$

[14] André Luís Luza, Gislene Lopes Gonçalves, Valério D. Pillar, Sandra Maria Hartz. Processes related to habitat selection, diversity and niche similarity in assemblages of non-volant small mammals at grassland-forest ecotones. Natureza \& Conservação, Volume 14, Issue 2, JulyDecember 2016, pp. 88-98. Available at: DOI: 10.1016/j.ncon.2016.09.003 [Accessed: Mar. 2, 2017].

[15] Koenig, W. D.. Global patterns of environmental synchrony and the Moran effect. - Ecography 25. 2002. pp. 283 - 288.

[16] Royama, T. Moran effect on nonlinear population processes. Ecological Monographs. 75. 2005, pp. 277-293. Available at: DOI:10.1890/04-0770. [Accessed: Mar. 3, 2017]

[17] Korosov A.V., Matrosova Yu.M., Bugmyrin S.V., Anikanova V.S., Bespyatova L.A. GIS-analysis of the factors of the territorial location of the bank vole (Clerthrionomys glareolus) in the mosaic landscape of South Karelia // Ecology. Experimental genetics and physiology. Proceedings of the Karelian Research Center of the Russian Academy of Sciences. Issue 11. Petrozavodsk, 2007. P. 70-84.

[18] A.V. Istomin, Influence of windfalls on dynamics of communities of small mammals in forests of southern taiga, Vestn. Mosk. Gos. Univ. Lesa - Lesnoi Vestn., 2009, no. 1, P. 196-201.

[19] T.Yu. Minayeva, A.V. Istomin, V.I. Abrazhko, Bazhenova T.P., Korablev N.P., Kuraeva $\quad$ E.N., Kurakina I.V., Pugatchevsky A.V., Rusanovich N.R. and Shaposhnikov E S 2001 Study on biota reaction on climate changes in the Central Forest Nature Reserve Climate Change Impact on Ecosystems. Nature Protected Areas in Russia. Analyses of Long-Term Information (Publications of WWF Russia) (Moscow: Russian University) pp 87-100 (in Russian)

[20] A. V. Istomin, The Role of "Blank" Stage in Supporting the Diversity of the Communities of Murine Rodents in Primary Spruce Forests of the Southern Taiga, in Biologicheskoe raznoobrazie lesnykh ekosistem (Biological Diversity of Forest Ecosystems), Moscow, 1995 . P. 144-146. 